\title{
Toxicity of Antiretrovirals on the Sea Urchin Echinometra lucunter and Its Predicted Environmental Concentration in Seawater from Santos Bay (Brazilian Coastal Zone)
}

\author{
Renato Sakai Cid $^{1,2}{ }^{(D}$, Vinicius Roveri ${ }^{3}$, Diogo Guedes Vidal ${ }^{4}\left(\mathbb{D}\right.$, Maria Alzira Pimenta Dinis ${ }^{4} \mathbb{D}_{\text {, }}$ \\ Fernando Sanzi Cortez ${ }^{2}$, Flávia Rigos Salgueiro ${ }^{1}$, Walber Toma ${ }^{1}$, Augusto Cesar ${ }^{2,5}$ \\ and Luciana Lopes Guimarães ${ }^{1, *}$
}

Citation: Cid, R.S.; Roveri, V.; Vidal, D.G.; Dinis, M.A.P.; Cortez, F.S.; Salgueiro, F.R.; Toma, W.; Cesar, A.; Guimarães, L.L. Toxicity of Antiretrovirals on the Sea Urchin Echinometra lucunter and Its Predicted Environmental Concentration in Seawater from Santos Bay (Brazilian Coastal Zone). Resources 2021, 10, 114. https://doi.org/10.3390/

resources10110114

Academic Editor: Diego Copetti

Received: 22 September 2021

Accepted: 5 November 2021

Published: 9 November 2021

Publisher's Note: MDPI stays neutral with regard to jurisdictional claims in published maps and institutional affiliations.

Copyright: (C) 2021 by the authors Licensee MDPI, Basel, Switzerland. This article is an open access article distributed under the terms and conditions of the Creative Commons Attribution (CC BY) license (https:// creativecommons.org/licenses/by/ $4.0 /)$.
1 Natural Products Research Laboratory, Santa Cecília University (UNISANTA), Rua Cesário Mota 8, F83A, Santos 11045-040, SP, Brazil; renatosakai@hotmail.com (R.S.C.); flaviarigos@gmail.com (F.R.S.); walbertoma@unisanta.br (W.T.)

2 Ecotoxicology Laboratory, Santa Cecília University (UNISANTA), Rua Oswaldo Cruz 266, Santos 11045-907, SP, Brazil; cortezfs@hotmail.com (F.S.C.); acesar@unifesp.br (A.C.)

3 Education Department, Metropolitan University of Santos (UNIMES), Avenida Conselheiro Nébias, 536, Encruzilhada, Santos 11045-002, SP, Brazil; viniciusroveri@bol.com.br

4 UFP Energy, Environment and Health Research Unit (FP-ENAS), Faculty of Science and Technology, University Fernando Pessoa (UFP), 4249-004 Porto, Portugal; diogovidal@ufp.edu.pt (D.G.V.); madinis@ufp.edu.pt (M.A.P.D.)

5 Department of Marine Sciences, Federal University of São Paulo, Rua Maria Máximo, 168, Santos 11030-100, SP, Brazil

* Correspondence: lucianafarm@unisanta.br

\begin{abstract}
Antiretrovirals (ARVs) have been detected in aquatic ecosystems throughout the world however, studies focused on assessing their ecotoxicological effects on marine aquatic organisms are still rare. In the present study, the predicted environmental concentration (PEC) of 13 ARVs was estimated for surface seawater from Santos Bay, Brazil, according to the European Medicines Agency (EMEA) guidelines. The results indicated that all ARVs need to be assessed for their ecological effects, considering that they all exceeded the EMEA guideline limits $(P E C>0.01 \mu \mathrm{g} \mathrm{L}-1)$. In this sense, three ARVs (namely atazanavir, nevirapine and efavirenz) were selected for the acute and chronic tests with sea urchin (Echinometra lucunter). Furthermore, the Environmental Risk Assessment (ERA) for these three ARVs was also performed by calculating the risk quotient. The acute and chronic toxicity results showed inhibitory concentrations $(I C)$ for the fertilization $\left(I_{50} ; 1 \mathrm{~h}\right.$; range: $\left.11.46-84.61 \mathrm{mg} \mathrm{L}^{-1}\right)$ and for the embryo-larval development $\left(I_{50} ; 42 \mathrm{~h}\right.$; range: $\left.0.52-0.97 \mathrm{mg} \mathrm{L}^{-1}\right)$ of the sea urchin, respectively. Moreover, the ERA showed that these three ARVs are potentially hazardous for aquatic life in Santos Bay, raising concerns about the continuous introduction of ARVs in aquatic ecosystems. The data presented may contribute to the provision of subsidies for the development of monitoring public policies that aim to reduce the introduction of ARVs into the aquatic environment.
\end{abstract}

Keywords: subtropical coastal zone; waste treatment; ocean dumping; antiretrovirals; predicted environmental concentration; ecotoxicology; risk assessment; pollution effects

\section{Introduction}

Currently, $40 \%$ of the world's population, estimated at 7.2 billion people, live in about 2100 coastal cities [1-3]. However, the high population concentration in the world's coastal cities raises some concerns because there are many people living in this small area of the world's land surface, estimated at between 4 and $8 \%$, thus causing intensive anthropic use of the narrow coastal areas $[2,4]$. Consequently, this high concentration of people exposes coastal ecosystems to different anthropogenic pressures, such as the disposal of 
municipal wastewater in the marine environment [5-7]. This sewage can contain thousands of chemical substances, such as pharmaceuticals and personal care products (PPCPs), that constitute a vast group of emerging environmental contaminants, from different therapeutic classes, including antiretroviral (ARV) drugs [8-10].

ARVs emerged in the 20th century when acquired immunodeficiency syndrome (AIDS) quickly spread across the five continents [11]. Nowadays, therapies with ARVs aim to reduce viral load, improving the host immune system once HIV mainly attacks the CD4+T cells, a crucial component in the body's immune system [12-14]. Based on their molecular mechanism of action, three classes of ARVs are widely used: (i) nucleoside/nucleotide reverse transcriptase inhibitors (NRTIs), namely abacavir, didanosine, lamivudine, tenofovir, and zidovudine; (ii) non-nucleoside reverse transcriptase inhibitors (NNRTIs), namely efavirenz, etravirine, and nevirapine; and (iii) protease inhibitors (PI), namely atazanavir, darunavir, lopinavir, ritonavir, and tipranavir. Each of these classes, represented by 13 ARVs, target a phase of the HIV virus life cycle [12-14]. Advances in ARVs treatment, essentially after the development of Highly Active Antiretroviral Therapy (HAART), a treatment regimen comprising a combination of three or more ARVs, made it possible to transform a syndrome, that was previously perceived to be a diagnostic to an announced death, into a disease with chronicity prospects [12-14].

The Joint United Nations Program on HIV / AIDS [11] estimates that 37.9 million people worldwide were living with HIV/AIDS in 2018. Consequently, after the high worldwide consumption of ARVs, these drugs have constantly been introduced into aquatic ecosystems through their main routes of human excretion, urine and faeces, a process that is allied to the absence or inefficacy of wastewater treatment plants (WWTPs) [8-10]. Several studies conducted in Norway [8], Kenya [15], Greece [9] and South Africa [10] reported high concentrations of ARVs, generally at $\mu \mathrm{g} \mathrm{L}^{-1}$ levels, in influents and effluents of WWTPs of the secondary treatment level (e.g., atazanavir, nevirapine and efavirenz). Moreover, the presence of ARVs in the aquatic environment was previously reported in different environmental matrices such as river water samples in South Africa (e.g., nevirapine, efavirenz and emtricitabine) and in sediments and waters of an estuary in France (namely abacavir, lamivudine, nelfinavir, nevirapine, ritonavir and saquinavir) $[16,17]$. However, despite the proven occurrence of ARVs in aquatic environments, there is a great scarcity of studies concerning the biological effects of ARVs in aquatic organisms, such as algae, crustaceans, fish and echinoderms, and especially in tropical marine organisms [18].

Specifically in Brazil, the fifth largest country in the world, where approximately 50 million people live in 463 coastal municipalities along $8500 \mathrm{~km}$ of coastline [19], there seems to exist no previous studies about the occurrence and the potential ecological risk of ARVs in different environmental matrices (e.g., seawater or sediment), despite the high incidence of the disease and the existence of a government program that distributes ARVs to those affected by HIV / AIDS. For instance, in 2018, 43,941 cases of HIV infection were reported in Brazil [11]. Currently, the Brazilian HIV / AIDS program, the budget of which is approximately US\$ 408 million/year, recommends an immediate start of ARV therapy for all people living with HIV, regardless of their clinical and/or immunological stage, and indicates that the initial therapy should always include combinations of three different ARVs, with two NRTIs associated with another class of ARVs. These ARVs are distributed for the 463 Brazilian coastal municipalities, among them Santos, the city that is the focus of this study, through a logistics management system-SILCOM/Ministry of Health [20-22]. The municipal sewage of Santos, in the State of São Paulo, is treated through a WWTP with a preliminary treatment [23-25]. This WWTP performs only a mechanical treatment, i.e., railing and screening for the removal of solids, that is followed by chlorination [23-25]. The final destination of the preconditioned sewage is a submarine outfall, which is $4500 \mathrm{~m}$ long and $10 \mathrm{~m}$ deep, that, on a daily basis, disposes of sewage into Santos Bay, South Atlantic Ocean, a semi-closed and low-energy coastal system [23-25]. Consequently, these ARVs (in parental, metabolized or conjugated forms in human excreta) can be released 
indiscriminately into the receiving waters of Santos Bay, because this WWTP is not efficient in removing these emerging pollutants $[8,9,15]$.

Considering this lack of data in the Brazilian coastal zone, the information about the prescription and/or consumption has been demonstrated to be very valuable in terms of estimating the occurrence of PPCPs in aquatic ecosystems [26]. According to the approach suggested by the European Medicines Agency (EMEA), the calculation of the predicted environmental concentration (PEC), based on consumption data, excretion, elimination in the WWTP, and dilution in receiving waters, constitutes extremely useful information to prioritize compounds for further monitoring, to establish the potential incidence of PPCPs in a specific area, and even to assess their risk according to toxicological data [26]. Further, the EMEA recommended the assessment of risk when PEC values in surface water were equal or above the threshold value of $0.01 \mu \mathrm{g} \mathrm{L}{ }^{-1}$ [26].

In this scenario of high consumption of ARVs in Brazil, combined with the lack of data regarding the biological effects of ARVs in marine organisms, this study estimated the concentration and potential ecological risk of 13 ARVs in the surface waters of Santos Bay, São Paulo, Brazil, through the PEC values. Moreover, the study employed ecotoxicological assays using sea urchins (Echinometra lucunter) as a test organism, with three selected ARVs: atazanavir, efavirenz and nevirapine. The data presented may contribute to the provision of subsidies for the development of monitoring government policies with the aim of reducing the introduction of ARVs into the aquatic environment and promoting good practices in the development and implementation of indicator systems regarding this urban issue.

\section{Materials and Methods}

\subsection{Predicted Environmental Concentration Calculation-PEC}

The PEC calculation of surface water of Santos Bay was performed according to the EMEA guideline [26], using the following Equation (1)

$$
\text { PEC Surface Waters }=\frac{\text { Maximum daily dose consumed per inhabitant } \times \text { Mpen }}{\text { Amount liquid waste }\left(\frac{\frac{L}{\text { inhabitant }}}{\text { day }}\right) \times \text { dilution factor }}
$$

considering:

Mpen = market penetration factor, Mpen [26], was calculated according to Equation (2)

$$
\operatorname{Mpen}(\%)=\frac{\text { Consumption }(m g / \text { year }) \times 100}{D D D(m g / \text { inhabitant } / \text { day }) \times \text { Pop } \times 365 \text { days }}
$$

considering:

$D D D=$ defined daily dose, according to the World Health Organization (WHO)

Pop $=$ number of the city inhabitants

Considering that the WWTP of Santos receives discharges from the cities of Santos and São Vicente, data were obtained from both cities [23-25]. According to the Brazilian Institute of Geography and Statistics data [19], the Santos population in 2018 was 432,957 inhabitants, and the São Vicente population was 363,173 inhabitants, totalling 796,130 inhabitants. According to the Basic Sanitation Company of São Paulo State [25], the amount of liquid waste/inhabitant/day is $575 \mathrm{~L}$. The dilution factor used is 10, and thus, the following values of Mpen and PEC were obtained and are included in Table 1.

Information regarding the number of distributed ARVs was obtained through access to the Federal Government website [27], where, through the Law on Access to Information (LAI) No. 12527/2011, annual withdrawal data were requested for the antiretroviral drugs dispensed in Santos and São Vicente municipalities, from July 2017 to July 2018. Liquid waste generation data were collected with the publications available online from SABESP and Environmental Protection Agency of the State of São Paulo [24]. 
Table 1. Mpen results for the antiretrovirals based on $D D D$.

\begin{tabular}{cccc}
\hline Antiretroviral & DDD (mg) & Annual & Consumed Amount (g) \\
\hline Abacavir & 600 & 14,625 & Mpen (\%) \\
\hline Atazanavir & 400 & 106,723 & 0.008388525 \\
\hline Darunavir & 600 & 158,805 & 0.091816852 \\
\hline Didanosine & 400 & 24 & 0.091082736 \\
\hline Efavirenz & 600 & 65,635 & 0.0000206478 \\
\hline Etravirine & 400 & 4560 & 0.037645122 \\
\hline Lamivudine & 300 & 94,802 & 0.003923088 \\
\hline Lopinavir & 1066 & 19,114 & 0.10874833 \\
\hline Nevirapine & 400 & 17,940 & 0.006170718 \\
\hline Ritonavir & 1200 & 64,061 & 0.015434252 \\
\hline Tenofovir & 300 & 9634 & 0.01837132 \\
\hline Tipranavir & 1000 & 540 & 0.011051751 \\
\hline Zidovudine & 600 & 169,750 & 0.00018583 \\
\hline Mpen $=$ market penetration factor; $D D D=$ defined daily dose, according to the World Health Organization (WHO).
\end{tabular}

\subsection{Ecotoxicological Assessment}

An EMEA [26] document establishes that if the PEC value is equal to or above $0.01 \mu \mathrm{g} \mathrm{L}^{-1}$, then the environmental fate should be investigated and effect assessment carried out. In this sense, toxicity tests were performed to assess the acute (fertilization rate) and chronic (embryo-larval development) effects using sea urchins (Echinometra lucunter), with three selected ARVs that presented PEC values above $0.01 \mu \mathrm{g} \mathrm{L}^{-1}$ : atazanavir (Nortec ${ }^{\circledR}$ Lab, Duque de Caxias, Rio de Janeiro, Brazil), nevirapine and efavirenz (Farmanguinhos, Fio Cruz ${ }^{\circledR}$ Lab, Manguinhos, Rio de Janeiro, Brazil). The organisms were collected through free diving, at Ilha das Palmas, in the municipality of Guarujá, São Paulo state, stored in a thermal box, and covered with the algae genus Ulva sp. The temperature conditions were maintained until transport to the laboratory, where they were kept in a tank, under strong aeration and ideal conditions, until the time of testing. The water used in the tanks was natural, originally collected on Ilha das Palmas. For these organism's maintenance, their physical-chemical parameters, such as temperature, salinity, $\mathrm{pH}$ and dissolved oxygen were observed daily, obeying the ideal conditions, according to the Brazilian NBR 15,350 standard [28]. For the test substances' dilution, gamete handling and control preparation, reconstituted water was used, from the mixture CORAL PRO SALT brand (RED SEA $^{\circledR}$, São Paulo, Brazil), composed of commercial salt in processed water, kept under agitation for total solubilization and preservation of the characteristics found in the organisms' natural environment. The solution was filtered, with a filtration support aid and $0.45 \mu \mathrm{m}$ Millipore ${ }^{\circledR}$ cellulose membrane. The water was maintained at a physical-chemical standard value of 15.350 ( $\mathrm{pH}$ between 7.8 and 8.4 and salinity between 30 and $37\left(\mathrm{~g} \mathrm{~L}^{-1}\right)$ [28]. A seawater control and a solvent (DMSO) control were set in parallel with the ARVs assays. There were no statistically significant differences between the control and the highest concentration of the DMSO solvent.

\subsubsection{Acute Toxicity Test (Fertilization Assay)}

The procedures were based on the USEPA protocol [29], adapted for the Echinometra lucunter species. Sea urchin sperm were exposed to different ARVs concentrations (3.12, $6.25,12.5,25,50$ and $100 \mathrm{mg} \mathrm{L}^{-1}$ ) during the 1-h period. After this period, a solution containing eggs was added to the test flasks. Twenty minutes after the addition of the eggs, the test was ended with the $0.5 \mathrm{~mL}$ borax-buffered formaldehyde addition in all replicates. After the exposure period, the test was ended with the addition of buffered 
formaldehyde. Afterwards, the reading was performed, and the effect concentration was estimated. At the end of the test, the larvae were divided into two groups, according to their morphological aspects, to identify normal and abnormal larvae. The test reading was performed by counting the first 100 organisms according to the development stage. For these tests, the results are expressed as $I C_{50}$ values (mean inhibitory concentrations) [28].

\subsubsection{Chronic Toxicity Tests (Embryo-Larval Development Assay)}

Newly fertilized sea urchin embryos were exposed to different ARV concentrations $\left(0.195,0.39,0.78,1.56\right.$ and $\left.3.12 \mathrm{mg} \mathrm{L}^{-1}\right)$ during the embryo-larval development period, that is, from $36 \mathrm{~h}$ to $42 \mathrm{~h}$ for Echinometra lucunter, according to the technical standard ABNT/NBR 15350 [28]. At the end of the test, the larvae were divided into 2 groups, according to their morphological aspects, to identify normal and abnormal larvae. The test reading was performed by counting the first 100 organisms according to the development stage. In these tests, the results are expressed as $I C_{50}$ (medium inhibitory concentration), NOEC (no observed effect on the concentration of the test organism) and LOEC (lowest observed that causes a statistically significant effect on the test organisms) [28].

\subsubsection{Environmental Risk Assessment (ERA)}

The Environmental Risk Assessment (ERA) for atazanavir, efavirenz and nevirapine to aquatic organisms was performed by calculating the risk quotient $(R Q)$ for 4 different aquatic organisms, algae, crustaceans, fish and echinoderms, following Equation (3)

$$
R Q=\frac{P E C}{P N E C}
$$

considering:

$R Q=$ Risk Quotient;

$P E C=$ Predicted Environmental Concentration;

$P N E C=$ Predicted No-Effect Concentration.

The PEC and PNEC values were predicted, and both were expressed in $\mu \mathrm{g} \mathrm{L}{ }^{-1}$. PNEC values were obtained from reliable base-set ecotoxicity data that were available for the aquatic compartment regarding short-term (Lethal Concentration $50\left(L C_{50}\right)$ or median Effective Concentration $\left(E C_{50}\right)$ ) and long-term (No Observed Effect Concentration (NOEC)) toxicological endpoints. According to the existent studies and current marine risk assessment practices, a reasonable correlation exists between the ecotoxicological responses of freshwater and saltwater biota, at least for the usual aquatic taxa (i.e., acute and chronic toxicity to algae, crustacean and fish) $[26,30,31]$. In this context, an attempt was made to specifically compile PNEC data for marine and coastal species. When these data were not available, data from freshwater communities were used. In order to collect the available ecotoxicity test endpoints, an extensive search was carried out in the Ecotoxicology Database (ECOTOX) from the United States Environmental Protection Agency [32], as well as in other literature sources using the PubMed database. When the experimentally-derived data from the ecotoxicity laboratory were not available short $\left[L(E) C_{50}\right]$ and long toxicological endpoints [Chv, geometric mean of NOEC and LOEC, ChV =10^ ([log (NOECxLOEC)]/2)] were estimated using the Ecological Structure Activity Relationships Program (ECOSAR, v 2.0) [33]. The derived PNEC values for the acute and chronic toxicity data were thereafter calculated by dividing each toxicological endpoint by an assessment factor $(A F)$. For saltwater environments, an $A F$ of 10,000 and 100 should be considered in short and long-term data sets. For further details, see the European Chemical Bureau [34] and the European Chemicals Agency [35] guidelines. Finally, the risk was categorized into four levels: no $(R Q<0.01)$, low $(0.01 \leq R Q<0.1)$, moderate $(0.1 \leq R Q<1.0)$ and high ecological risk $(R Q \geq 1.0)$ to aquatic organisms [36]. 


\subsection{Statistical Analysis}

The linear interpolation method was used to calculate the set of inhibitory concentrations $\left(I C_{50}\right)(1 \mathrm{~h})$ for the fertilization assays and the set of $I C_{50}(42 \mathrm{~h})$ for the embryo-larval development assays, using the ICPin program. For each embryo-larval development assay, ANOVA followed by the Dunnett's test were used to identify the concentrations that were significantly different from the control (NOEC and LOEC). For all analyses, significant differences were determined when $p<0.05$. Statistical analysis was performed by employing TOXSTAT 3.5.

\section{Results and Discussion}

\subsection{Predicted Environmental Concentration Calculation-PEC}

Predictive models have been used as an approach for investigating the presence of pharmaceuticals in the environment, especially in hospitals and WWTP effluents [37,38]. $P E C$ is an estimation of the concentration of a substance in the environment, considering the initial amount released into the environment in terms of its fate, transformation and removal, either by artificial or natural means $[13,26]$. In the present study, it was possible to estimate ARV PEC values for Santos Bay surface waters considering that ARV dispensation and stocks in Brazil are monitored by the logistics management system-SILCOM/Ministry of Health [20-22]. The PEC values are shown in Table 2. Of the 13 drugs assessed, didanosine displayed a $P E C$ value equal the EMEA document limit $\left(0.01 \mu \mathrm{g} \mathrm{L}^{-1}\right)$ and the other $12 \mathrm{ARVs}^{\prime}$ PEC values were above the limit, indicating that all ARVs included in this study need to be assessed in terms of the destination and the environmental effect of this compound [26].

Table 2. Predicted environmental concentration (PEC surface waters) values of antiretrovirals (ARVs) in seawater from Santos Bay (Brazil).

\begin{tabular}{ccc}
\hline Therapeutic Classes & ARV & PEC $\left(\boldsymbol{\mu g} \mathbf{~ L}^{-\mathbf{1}}\right)$ \\
\hline \multirow{3}{*}{ NRTI } & Abacavir & 0.875 \\
& Didanosine & 0.001 \\
& Lamivudine & 5.673 \\
& Tenofovir & 0.576 \\
ZNRTI & Zidovudine & 10.159 \\
\hline \multirow{2}{*}{ NNfavirenz } & 3.928 \\
& Etravirine & 0.272 \\
& Nevirapine & 1.073 \\
\hline \multirow{2}{*}{ PI } & Atazanavir & 6.387 \\
& Darunavir & 9.504 \\
& Lopinavir & 1.143 \\
& Ritonavir & 3.834 \\
\hline
\end{tabular}

Nucleoside reverse transcriptase inhibitor (NRTI); non-nucleoside reverse transcriptase inhibitor (NNRTI); protease inhibitor (PI).

For the NRTI class, zidovudine and lamivudine presented the highest PEC values (10.159 and $5.673 \mu \mathrm{g} \mathrm{L}^{-1}$, respectively). The combination of zidovudine and lamivudine is one of the most studied in randomized clinical trials and is usually well tolerated for HIV / AIDS treatment, and it can also be used in schemes for postexposure prophylaxis (PEP) in situations involving potential exposure to HIV. It is available in co-formulation, which contributes to greater dose comfort [22]. Since 1999, Brazil have offered PEP as a strategy against HIV transmission [20,39]. The presence of both zidovudine and lamivudine and other ARVs was reported in WWTP effluents and river water in France [16]. The presence of zidovudine and carboxy-lamivudine (a stable carboxy-transformation product of lamivudine formed in WWTPs) was reported in surface waters in Germany [40].

Regarding the NNRTI class, the highest PEC value was observed for efavirenz (3.928 $\left.\mu \mathrm{g} \mathrm{L}^{-1}\right)$ followed by nevirapine $\left(1.073 \mu \mathrm{g} \mathrm{L}^{-1}\right)$. According to the Brazilian Clin- 
ical protocol and guidelines, therapeutics for the management of HIV infections in adult women of childbearing age at the start of treatment should preferably involve the use of regimens containing efavirenz and the performance of pre-treatment genotyping [22]. Both efavirenz and nevirapine were detected in dam and ground waters in South Africa [17] and they were also detected in WWTP effluents in Kenya [15].

Among the protease inhibitors (PI) included in this study, darunavir and atazanavir presented the highest $P E C$ values (9.504 and $6.387 \mu \mathrm{g} \mathrm{L}{ }^{-1}$, respectively). Atazanavir is the first option in the IP class among the ARVs of choice for first failure of HIV treatment rescue, and darunavir is used as an alternative for contraindication, intolerance or proven toxicity to atazanavir, according to the Brazilian treatment guidelines [22]. The occurrence of atazanavir was previously reported in WWTP effluents in Norway [8] and darunavir was detected in water samples (tap and river) in Poland [41]. Furthermore, Ncube et al. [13] mentioned that some ARVs, such as nevirapine and atazanavir, are persistent enough to by-pass most conventional wastewater treatment processes and remain in surface waters. ARVs can also reach water sources and enter food chains.

In the coastal areas of Brazil, there are 20 conventional WWTPs, such as Santos, that, on a daily basis, dispose of their sewer contents into the Atlantic Ocean [23-25]. These WWTPs are not efficient in removing these 13 ARVs. Consequently, these chemical stressors (in parental, metabolized or conjugated forms in human excreta) can be released indiscriminately into the receiving waters of the Brazilian coastline $[8,9,15]$. It is worth mentioning that there are advanced wastewater technologies that potentially remove ARVs residues (e.g., ozonation and activated carbon) but they are usually expensive to adopt in developing countries such as Brazil [13].

In the present study, eight $\mathrm{ARV}$ s displayed high $P E C$ values, exceeding $100 \times$ the EMEA PEC values limits. Three of them were selected to perform acute and chronic toxicity tests with Echinometra lucunter: atazanavir, efavirenz and nevirapine.

\subsection{Acute and Chronic Toxicity Tests}

This study assessed the biological effects of atazanavir, efavirenz and nevirapine in different life stages of the sea urchin Echinometra lucunter through fertilization and embryo-larval development assays (acute and chronic toxicity tests, respectively). The mean concentrations that inhibited the fertilization of Echinometra lucunter $\left(I C_{50} ; 1 \mathrm{~h}\right)$ were: $73.04 \mathrm{mg} \mathrm{L}^{-1}$ for atazanavir; $11.46 \mathrm{mg} \mathrm{L}^{-1}$ for efavirenz; and $84.61 \mathrm{mg} \mathrm{L}^{-1}$ for nevirapine. These results are presented in Table 3. It is noteworthy to mention that of these three compounds, efavirenz demonstrated the highest toxicity in acute tests, and also displayed the highest octanol-water partitioning coefficient (Kow), with a log Kow value of 4.7 for efavirenz, as compared 4.54 for atazanavir and 2.5 for nevirapine. Normally, log Kow $\geq 3$ indicates that ARVs could bioaccumulate and/or exert toxicity [26,32,33].

Table 3. Results of the fertilization assays ( $n=4)$ of antiretrovirals (ARVs) (IC $C_{50}$ and confidence limits) on Echinometra lucunter.

\begin{tabular}{ccc}
\hline ARV & $\mathbf{I C}_{\mathbf{5 0}}\left(\mathbf{m g ~ L}^{-\mathbf{1}}\right)$ & $\begin{array}{c}\text { Lower-Upper } \\
\text { Confidence Intervals }\end{array}$ \\
\hline Atazanavir & 73.04 & $71.98-73.90$ \\
Efavirenz & 11.46 & $11.18-11.81$ \\
Nevirapine & 84.61 & $80.79-89.35$ \\
\hline
\end{tabular}

$\overline{I C} C_{50}=$ average inhibitory concentration.

In the embryo-larval development assay, the mean concentrations of ARVs that inhibited the normal embryo-larval development of Echinometra lucunter $\left(I C_{50} ; 42 \mathrm{~h}\right)$ were: $0.63 \mathrm{mg} \mathrm{L}^{-1}$ for atazanavir; $0.52 \mathrm{mg} \mathrm{L}^{-1}$ for efavirenz; and $0.195 \mathrm{mg} \mathrm{L}^{-1}$ for nevirapine (Table 4). 
Table 4. Results of the embryo-larval assays $(n=4)$ of antiretrovirals (ARVs) (NOEC, LOEC, and $I_{50}$ ) on Echinometra lucunter.

\begin{tabular}{cccc}
\hline ARV & LOEC $\left(\mathbf{m g ~ L}^{-\mathbf{1}}\right)$ & NOEC $\left(\mathbf{m g ~ L}^{-\mathbf{1}}\right)$ & IC $_{\mathbf{5 0}}\left(\mathbf{m g ~ L}^{-\mathbf{1}}\right)$ \\
\hline Atazanavir & 0.78 & 0.39 & $0.63(0.62-0.64)$ \\
Efavirenz & 0.195 & 0.0975 & $0.52(0.50-0.53)$ \\
Nevirapine & 0.39 & 0.195 & $0.97(0.95-0.98)$ \\
\hline
\end{tabular}

$\overline{L O E C}=$ lowest observed effect concentration; NOEC: no observed effect concentration.

Even when present in low concentrations, PPCPs have the ability to persist in the environment, which increases the possibility of the occurrence of chronic effects, since many aquatic species are continuously exposed to these pollutants for long time periods or throughout the life cycle [26,33,42]. According to Daouk et. al. [43], ARVs can be seen as pseudo-pollutants that are persistent in the environment because of their continuous release. It should be noted that studies involving toxicity assays with ARVs are rare, especially in marine organisms. Robson et al. [44] have demonstrated that acute (96 h) exposure of Oreochromis mossambicus to $20.6 \mathrm{ng} \mathrm{L}^{-1}$ of efavirenz resulted in liver damage and an overall decline in fish health, when compared to control fish. Ngumba et al. [45] calculated the $R Q$ values of nevirapine for aquatic life and observed that the chemical presented potential ecotoxicological effects on algae, daphnia and fish. Considering this scenario, in the present study, ERA was performed with atazanavir, efavirenz and nevirapine.

\subsection{Environmental Risk Assessment (ERA)}

The ERA of pharmaceuticals released in the aquatic environment is very important to protect the environmental and public health. Hence, considering the worst-case scenario in accordance with the Technical Guidance Document on Risk Assessment of the European Union [46], an environmental risk assessment screening was conducted for atazanavir, efavirenz and nevirapine.

For Echinoderm, the PNEC was estimated from data obtained in the present study, specifically the acute and chronic toxicity assay with Echinometra lucunter. On the other hand, for algae, crustacean and fish, $100 \%$ of the acute and chronic PNEC were estimated using the ECOSAR program, as described in Table 5. It is noteworthy to mention that the lack of data regarding toxicity with marine organisms with ARVs led the authors to use toxicity data from freshwater species to calculate the PNEC, highlighting the importance of ecotoxicological studies with ARVs, especially with tropical marine organisms.

Table 5. Results from the Environmental Risk Assessment tests regarding the antiretroviral drugs Atazanavir, Efavirenz and Nevirapine.

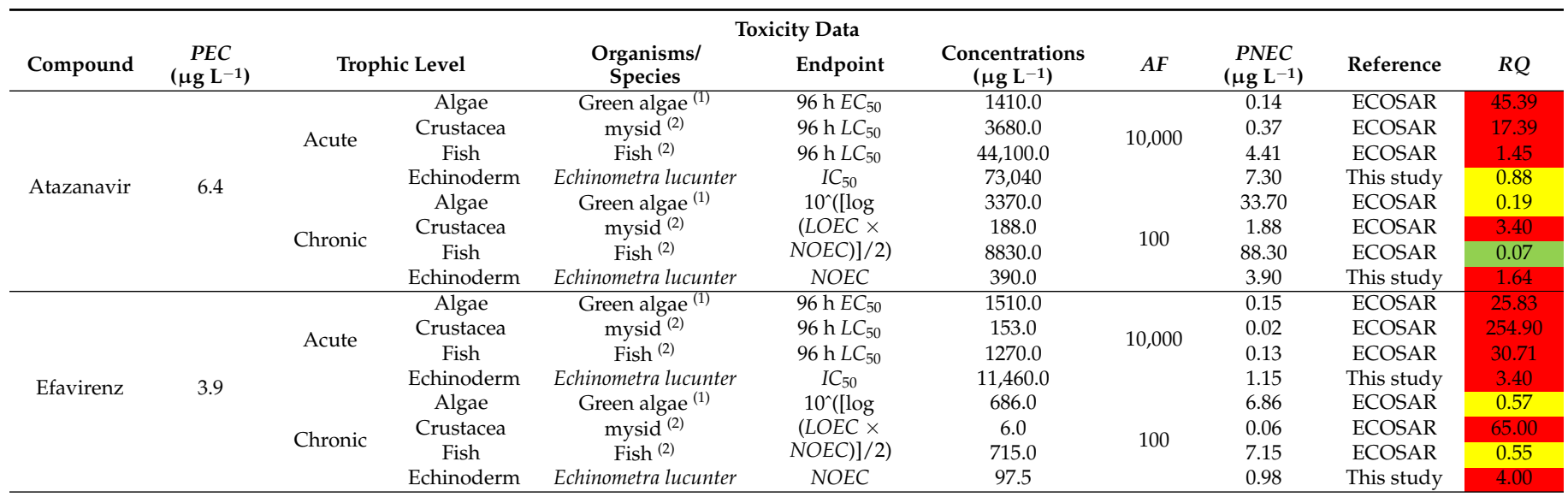


Table 5. Cont.

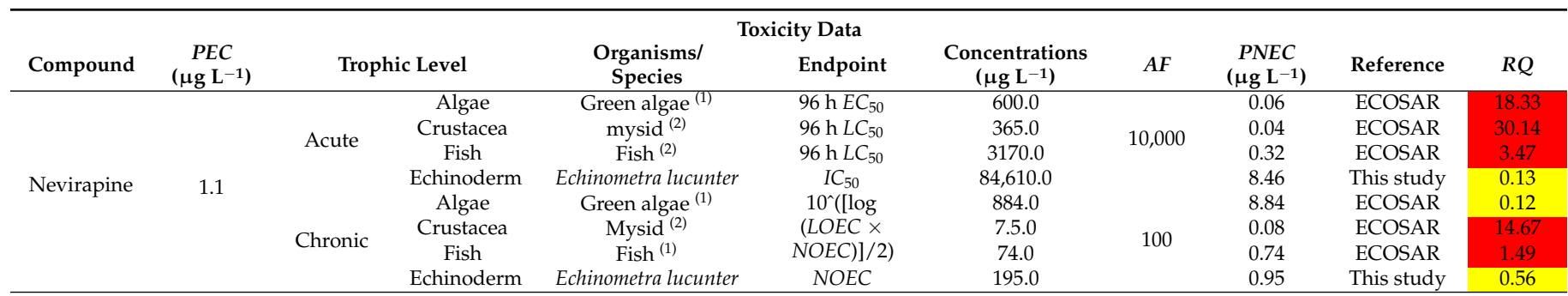

Notes: PEC (predicted environmental concentration) (in $\left.\mu \mathrm{g} \mathrm{L}^{-1}\right)$; acute and chronic toxicity data: ((trophic level; freshwater or seawater organisms/species; endpoint and concentrations ( $\left.\mu \mathrm{g} \mathrm{L}^{-1}\right)$; $A F$ : assessment factor; PNEC: predicted no-effect concentration $\left.\left(\mu \mathrm{g} \mathrm{L}^{-1}\right)\right)$ obtained from the ECOSAR program [33]. In the last column, risk quotients $(R Q)$ for the acute and chronic tests (i.e., without risk, signalled in white; low risk, signalled in green; medium risk, signalled in yellow; and high risk, signalled in red) (for more details, see Section 2.2.3); freshwater ${ }^{(1)}$; seawater ${ }^{(2)} ; E C_{50}: 50 \%$ effective concentration; $L C_{50}: 50 \%$ lethal concentration; NOEC: no observed effect concentration; and $L O E C$ : lowest observed effect concentration; $I C_{50}=$ average inhibitory concentration.

The results obtained revealed that atazanavir showed high risks of acute toxicity for green algae, mysid and fish, and moderate risk for Echinometra lucunter sea urchin. In the chronic assessment, atazanavir displayed low risk for fish and moderate/high risks for the other organisms included in this assessment. Efavirenz displayed high risks in acute toxicity for all organisms and medium to high risks in the chronic risk assessment. For nevirapine, a high risk was observed for almost all organisms in the acute assessment, and a high/moderate risk was observed in the chronic assessment.

The data presented here suggest that atazanavir, efavirenz and nevirapine are potentially dangerous in Santos Bay waters. Despite this, the hypothesis that the mixtures of these compounds produce synergistic effects, which may potentiate their individual effects, in the environment, cannot be ruled out, as the toxicity tests were performed with isolated compounds. Furthermore, human metabolites must also be considered for further ecotoxicological studies to assess the acute and chronic toxicity of these compounds. In fact, although most drugs can undergo biotransformation, they can still be excreted in the active form, and can accumulate in other organisms or in the environment [26,33,47].

\section{Conclusions}

In Brazil, the use of ARVs is widely disseminated among the HIV/AIDS population through the unified, universal and free-of-charge public health system (SUS). ARVs are also used as prevention tool against HIV infection through PEP. It is worth mentioning that the modern and efficient decentralized HIV testing capability of the Brazilian HIV / AIDS program results in an increasing number of HIV+ patients in Brazil's health system. Considering the high consumption of ARVs in Brazil and the main routes of excretion of these pharmaceuticals (urine and faeces), the PEC values of $13 \mathrm{ARVs}$ in the surface waters of Santos Bay, Brazil, were estimated. The results revealed that all of the ARVs included in this study need to be assessed for their environmental fate and an analysis of their effects on aquatic organisms needs to be conducted, according to the limits established by the EMEA guidelines. In the present study, acute and chronic toxicity tests were performed with atazanavir, efavirenz and nevirapine to gametes and embryos of the sea urchin Echinometra lucunter, constituting one of the few studies carried out with ARVs in aquatic (marine) organisms. The ERA, which was also performed here, showed that atazanavir, efavirenz and nevirapine are potentially hazardous for aquatic life in Santos Bay waters, which raises concerns about the continuous introduction of ARVs in aquatic ecosystems. The data presented here may contribute to the provision of subsidies for the development of regular government programs to monitor ARVs levels in Effluent Treatment Stations, as well as to the development of solutions to reduce and/or eliminate the releasing of ARVs into the aquatic environment. Future research will focus on the development of new experiments, using different marine media such as algae, with a combination of the compounds included in this study as well as using the real concentrations found in the sea, in order to assess their effects on different sea organisms. 
Author Contributions: Conceptualization, R.S.C.; Data curation, R.S.C.; Formal analysis, R.S.C. and V.R.; Investigation, R.S.C. and V.R.; Methodology, R.S.C.; Resources, R.S.C.; Software, R.S.C.; Supervision, L.L.G.; Validation, V.R., D.G.V., M.A.P.D., F.S.C., F.R.S., W.T., A.C. and L.L.G.; Visualization, V.R., D.G.V., M.A.P.D., F.S.C., F.R.S., W.T., A.C. and L.L.G.; Writing-original draft, R.S.C.; Writing-review and editing, V.R., D.G.V., M.A.P.D., F.S.C., F.R.S., W.T., A.C. and L.L.G. All authors have read and agreed to the published version of the manuscript.

Funding: A. Cesar thanks the National Council, known as CNPq (Conselho Nacional de Desenvolvimento Científico e Tecnológico, MEC-Brazil), for his research productivity fellowship (PQ\#305869/2013-2). R. S. Cid thanks CAPES (Coordenação de Aperfeiçoamento de Pessoal de Nível Superior) for his research fellowship.

Institutional Review Board Statement: Not applicable.

Informed Consent Statement: Not applicable.

Data Availability Statement: The data used in this study are available in the manuscript.

Acknowledgments: The authors are grateful for the important comments and suggestions raised by the anonymous reviewers.

Conflicts of Interest: The authors declare no conflict of interest.

\section{References}

1. Blackburn, S.; Pelling, M.; Marques, C. Megacities and the Coast: Global Context and Scope for Transformation. In Coasts and Estuaries the Future; Elsevier: Amsterdam, The Netherlands, 2019; pp. 661-669.

2. United Nations-Department of Economic and Social Affairs-Population Division. World Urbanization Prospects: The 2018 Revision (ST/ESA/SER.A/420); United Nations: New York, NY, USA, 2019; Volume 12, ISBN 9789211483192.

3. Oliveira, G.M.; Vidal, D.G.; Ferraz, M.P. Urban Lifestyles and Consumption Patterns. In Sustainable Cities and Communities. Encyclopedia of the UN Sustainable Development Goals; Filho, W.L., Azul, A.M., Brandli, L., Özuyar, P.G., Wall, T., Eds.; Springer Nature Switzerland AG: Cham, Switzerland, 2020; pp. 851-860, ISBN 978-3-319-71061-7.

4. Barragán, J.M.; de Andrés, M. Analysis and trends of the world's coastal cities and agglomerations. Ocean Coast. Manag. 2015, 114, 11-20. [CrossRef]

5. Dafouz, R.; Cáceres, N.; Rodríguez-Gil, J.L.; Mastroianni, N.; de Alda, M.L.; Barceló, D.; de Miguel, Á.G.; Valcárcel, Y. Does the presence of caffeine in the marine environment represent an environmental risk? A regional and global study. Sci. Total Environ. 2018, 615, 632-642. [CrossRef]

6. Desbiolles, F.; Malleret, L.; Tiliacos, C.; Wong-Wah-Chung, P.; Laffont-Schwob, I. Occurrence and ecotoxicological assessment of pharmaceuticals: Is there a risk for the Mediterranean aquatic environment? Sci. Total Environ. 2018, 639, 1334-1348. [CrossRef] [PubMed]

7. Ojemaye, C.Y.; Petrik, L. Pharmaceuticals in the marine environment: A review. Environ. Rev. 2019, 27, 151-165. [CrossRef]

8. Ferrando-Climent, L.; Reid, M.J.; Rodriguez-Mozaz, S.; Barceló, D.; Thomas, K.V. Identification of markers of cancer in urban sewage through the use of a suspect screening approach. J. Pharm. Biomed. Anal. 2016, 129, 571-580. [CrossRef] [PubMed]

9. Ibañez, M.; Borova, V.; Boix, C.; Aalizadeh, R.; Bade, R.; Thomaidis, N.; Hernández, F. UHPLC-QTOF MS screening of pharmaceuticals and their metabolites in treated wastewater samples from Athens. J. Hazard. Mater. 2017, 323, 26-35. [CrossRef]

10. Schoeman, C.; Dlamini, M.; Okonkwo, O. The impact of a Wastewater Treatment Works in Southern Gauteng, South Africa on efavirenz and nevirapine discharges into the aquatic environment. Emerg. Contam. 2017, 3, 95-106. [CrossRef]

11. UNAIDS Data e Trends: Global Statistics. Available online: https://www.hiv.gov/hiv-basics/overview/data-and-trends/globalstatistics (accessed on 4 March 2021).

12. Domingues, C.-S.B.; Waldman, E.A. Causes of Death among People Living with AIDS in the Pre- and Post-HAART Eras in the City of São Paulo, Brazil. PLoS ONE 2014, 9, e114661. [CrossRef]

13. Ncube, S.; Madikizela, L.M.; Chimuka, L.; Nindi, M.M. Environmental fate and ecotoxicological effects of antiretrovirals: A current global status and future perspectives. Water Res. 2018, 145, 231-247. [CrossRef]

14. Ginat, D.T.; Schaefer, P.W. Highly Active Antiretroviral Therapy (HAART); Ginat, D., Small, J., Schaefer, P., Eds.; Neuroimaging Pharmacopoeia; Springer: Cham, Switzerland, 2015.

15. K'Oreje, K.; Vergeynst, L.; Ombaka, D.; De Wispelaere, P.; Okoth, M.; Van Langenhove, H.; Demeestere, K. Occurrence patterns of pharmaceutical residues in wastewater, surface water and groundwater of Nairobi and Kisumu city, Kenya. Chemosphere 2016, 149, 238-244. [CrossRef]

16. Aminot, Y.; Litrico, X.; Chambolle, M.; Arnaud, C.; Pardon, P.; Budzinski, H. Erratum to: Development and application of a multi-residue method for the determination of 53 pharmaceuticals in water, sediment, and suspended solids using liquid chromatography-tandem mass spectrometry. Anal. Bioanal. Chem. 2015, 407, 8623. [CrossRef] 
17. Rimayi, C.; Odusanya, D.; Weiss, J.; de Boer, J.; Chimuka, L. Contaminants of emerging concern in the Hartbeespoort Dam catchment and the uMngeni River estuary 2016 pollution incident, South Africa. Sci. Total Environ. 2018, 627, 1008-1017. [CrossRef] [PubMed]

18. Nannou, C.; Ofrydopoulou, A.; Evgenidou, E.; Heath, D.; Heath, E.; Lambropoulou, D. Antiviral drugs in aquatic environment and wastewater treatment plants: A review on occurrence, fate, removal and ecotoxicity. Sci. Total Environ. 2020, 699, 134322. [CrossRef] [PubMed]

19. Instituto Brasileiro de Geografia e Estatística (IBGE). Available online: https:/ / cidades.ibge.gov.br/ (accessed on 30 August 2021).

20. Benzaken, A.S.; Pereira, G.F.M.; Costa, L.; Tanuri, A.; Santos, A.F.; Soares, M.A. Antiretroviral treatment, government policy and economy of HIV/AIDS in Brazil: Is it time for HIV cure in the country? AIDS Res. Ther. 2019, 16, 1-7. [CrossRef] [PubMed]

21. Brazil Lei, No. 313, de 13 de Novembro de 1996, Dispõe Sobre a Distribuição Gratuita de Medicamentos aos Portadores do HIV e Doentes de AIDS [Law No. 9313, of November 13, 1996, Provides for the Free Distribution of Medication to HIV Carriers and AIDS Patients]. Available online: https:/ / www.planalto.gov.br/ccivil_03/leis/19313.htm (accessed on 4 March 2021).

22. Brazil. Ministério da Saúde Clinical Protocol and Guidelines Therapeutics for Management of Infection by HIV in Adults. Available online: http:/ / www.aids.gov.br/pt-br/profissionais-de-saude/hiv/protocolos-clinicos-e-manuais (accessed on 13 April 2021).

23. Abessa, D.M.D.S.; Rachid, B.R.D.F.; Moser, G.A.D.O.; Oliveira, A.J.F.C. Environmental effects of sewage oceanic disposal by submarine outfalls: A review. Mundo O Da 2012, 36, 643-661. [CrossRef]

24. Cetesb-Companhia Estadual de Tecnologia e Saneamento ambiental. Relatório de Qualidade das Águas Costeiras no Estado de São Paulo 2018 [Report on the Quality of Coastal Waters in the State of São Paulo 2018]; Cetesb: São Paulo, Brazil, 2018.

25. SABESP. Companhia de Saneamento Básico do Estado de São Paulo [Basic Sanitation Company of the State of São Paulo]. Available online: http:/ / site.sabesp.com.br/ (accessed on 4 March 2021).

26. EMEA-European Medicines Agency, C. for M.P. for H. Use (CHMP). Guideline on the Environmental Risk Assessment of Medicinal Products for Human Use: Doc. Ref.: EMEA/CHMP/SWP/4447/00 corr 1; EMEA: London, UK, 2006.

27. Governo Federal Federal Government Website. Available online: http://www.acessoainformacao.gov.br (accessed on 13 March 2021).

28. ABNT Ecotoxicologia. Aquática-Toxicidade Crônica de Curta Duração-Método de Ensaio com Ouriço-do-mar (Echinodermata: Echinoidea) [Aquatic Ecotoxicology—Short Term Chronic Toxicity—Sea Urchin Test Method]-NBR 15350; ABNT: Rio de Janeiro, Brazil, 2012.

29. USEPA-United States Environmental Protection Agency Sperm Cell Toxicity Tests Using the Sea Urchin (Arbacia punctulata) EPA 833-C-09-001. Available online: https://www.epa.gov/sites/production/files/2015-09/documents/seaurchintesting.pdf (accessed on 1 March 2021).

30. Li, Y.-X.; Zhang, X.-L.; Li, W.; Lu, X.-F.; Liu, B.; Wang, J. The residues and environmental risks of multiple veterinary antibiotics in animal faeces. Environ. Monit. Assess. 2013, 185, 2211-2220. [CrossRef]

31. Thomaidi, V.S.; Stasinakis, A.S.; Borova, V.L.; Thomaidis, N. Is there a risk for the aquatic environment due to the existence of emerging organic contaminants in treated domestic wastewater? Greece as a case-study. J. Hazard. Mater. 2015, 283, 740-747. [CrossRef]

32. USEPA. United States Environmental Protection Agency ECOTOX User Guide: Ecotoxicology Database System; USEPA: Washington, DC, USA, 2019.

33. USEPA. United States Environmental Protection Agency Ecological Structure-Activity Relationship Model (ECOSAR) Class Program; USEPA: Washington, DC, USA, 2017.

34. De Bruijn, J.; Hansen, B.; Johansson, S.; Luotamo, M.; Munn, S.; Musset, C.; Olsen, S.; OlssoN, H.; Paya-Perez, A.; Pedersen, F.; et al. Technical Guidance Document on risk Assessment; Part 1. Part 2; European Commission: Brussels, Belgium, 2002.

35. European Chemicals Agency. Guidance on Information Requirements and Chemical Safety Assessment Chapter R.10: Characterisation of Dose [Concentration]-Response for Environment; Dictus Publishing: Chisinau, Moldova, 2008.

36. Hernando, M.D.; Mezcua, M.; Alba, A.R.F.; Barceló, D. Environmental risk assessment of pharmaceutical residues in wastewater effluents, surface waters and sediments. Talanta 2006, 69, 334-342. [CrossRef]

37. Escher, B.I.; Baumgartner, R.; Koller, M.; Treyer, K.; Lienert, J.; McArdell, C.S. Environmental toxicology and risk assessment of pharmaceuticals from hospital wastewater. Water Res. 2011, 45, 75-92. [CrossRef]

38. Minguez, L.; Pedelucq, J.; Farcy, E.; Ballandonne, C.; Budzinski, H.; Halm-Lemeille, M.-P. Toxicities of 48 pharmaceuticals and their freshwater and marine environmental assessment in northwestern France. Environ. Sci. Pollut. Res. 2016, $23,4992-5001$. [CrossRef]

39. Brazil. Ministério da Saúde Clinical Protocol and Therapeutic Guidelines for Post-Exposure Prophylaxis (PEP) for the Risk of HIV, STIs and Viral Hepatitis Infections. Available online: http:/ / www.aids.gov.br/pt-br/pub/2015/protocolo-clinico-e-diretrizesterapeuticas-para-profilaxia-pos-exposicao-pep-de-risco (accessed on 4 March 2021).

40. Funke, J.; Prasse, C.; Ternes, T.A. Identification of transformation products of antiviral drugs formed during biological wastewater treatment and their occurrence in the urban water cycle. Water Res. 2016, 98, 75-83. [CrossRef] [PubMed]

41. Giebułtowicz, J.; Tyski, S.; Wolinowska, R.; Grzybowska, W.; Zaręba, T.; Drobniewska, A.; Wroczyński, P.; Nałęcz-Jawecki, G. Occurrence of antimicrobial agents, drug-resistant bacteria, and genes in the sewage-impacted Vistula River (Poland). Environ. Sci. Pollut. Res. 2018, 25, 5788-5807. [CrossRef] [PubMed] 
42. Jones, O.A.H.; Voulvoulis, N.; Lester, J.N. Ecotoxicity of pharmaceuticals. Compr. Anal. Chem. 2007, 50, $387-424$.

43. Daouk, S.; Chèvre, N.; Vernaz, N.; Bonnabry, P.; Dayer, P.; Daali, Y.; Fleury-Souverain, S. Prioritization methodology for the monitoring of active pharmaceutical ingredients in hospital effluents. J. Environ. Manag. 2015, 160, 324-332. [CrossRef] [PubMed]

44. Robson, L.; Barnhoorn, I.; Wagenaar, I. The potential effects of efavirenz on Oreochromis mossambicus after acute exposure. Environ. Toxicol. Pharmacol. 2017, 56, 225-232. [CrossRef]

45. Ngumba, E.; Gachanja, A.; Tuhkanen, T. Occurrence of selected antibiotics and antiretroviral drugs in Nairobi River Basin, Kenya. Sci. Total Environ. 2016, 539, 206-213. [CrossRef]

46. European Commission. Technical Guidance Document on Risk Assessment for Existing Substances, Part II; European Commission: Brussels, Belgium, 2003.

47. Mompelat, S.; Le Bot, B.; Thomas, O. Occurrence and fate of pharmaceutical products and by-products, from resource to drinking water. Environ. Int. 2009, 35, 803-814. [CrossRef] 